\title{
Is Portfolio Assessment Effective in Improving Iranian EFL Students' Writing?
}

\author{
Mansoreh Sepasdar \\ Department of Language and Literature, Larestan Branch \\ Islamic Azad University, Larestan, Iran \\ E-mail: maryamartlover@yahoo.com \\ Hadiseh Esmaeeli \\ Department of Language and Literature, Larestan Branch \\ Islamic Azad University, Larestan, Iran \\ E-mail: yas.yas2100@gmail.com \\ Zahra Sherafat \\ Department of Language and Literature, Larestan Branch \\ Islamic Azad University, Larestan, Iran \\ E-mail: elnaz.shm@gmail.com
}

Received: 10-07- 2014

doi:10.7575/aiac.ijels.v.2n.4p.1
Accepted: 10-09-2014

URL: http://dx.doi.org/10.7575/aiac.ijels.v.2n.4p.1
Published: $30-10-2014$

\begin{abstract}
The current study explored the effect of portfolio assessment on the improvement of the Iranian students' writing. Additionally, students' attitudes towards using portfolio were investigated. Participants of the study were 46 preintermediate Iranian male and female university students who were chosen from a larger group of 70 students. They were divided randomly into experimental and control groups with equal number of students of 23 in each group. All the students in experimental group wrote five essays based on the topics in their course book. To evaluate the students' writings, word choice, ideas, sentence fluency, voice, and organization were checked by two experienced rates. In contrast, the students in control group wrote five essays and they didn't receive any feedback from their teacher and also they didn't have any opportunity to revise their writing papers. The findings of the study revealed that portfolio assessment had a positive effect on the overall writing ability among the Iranian university students.
\end{abstract}

Keywords: portfolio assessment, writing ability, scoring, EFL students

\section{Introduction}

One important trend which has changed the world of language assessment is portfolio which is effective for the students in skill development especially for writing courses. Portfolio assessment is defined as "a collection of texts the writer has produced over a defined period of time" (Hamp-lyons, 1995, p.262). Since learners can check multifaceted process of writing skill, they learn better through portfolio assessment.

In fact, portfolio assessment is considered as a valuable assessment tool in the world of education (Barrett, 2000; Biggs and Tang, 1997; Cooper, 1997). It is pedagogically helpful because it enables the educators to overcome some assessment problems (Cooper, 1999; Cooper and Love, 2000). Portfolio gives a "richer picture" of the students (Barrett, $2000 \mathrm{~b}$ ); and it can involve the students in the active learning process (Bowie, Taylor, Zimitat, \& Young, 2000). Hedge (2000) refers to portfolio assessment as a comprehensive portrait of the students' writing. In this case, portfolio assessment rather than one impromptu timed writing will help teachers to have a better judgment about students' writing ability. Moreover, portfolio assessment will assist teachers to give feedback that informs both teaching and learning (Dysthe, 2008). This informative function of portfolio assessment can be investigated in an EFL context (Lam \& Lee, 2010).

\section{The Appearance of Portfolio Assessment}

Portfolio assessment was an issue which attracted the attention of many researchers around the mid-1980s "as a reaction against the psychometric climate prevailing at the time" (Taki and Heidari, 2011, p. 192). Regarding the portfolio assessment, Elbow and Belandoff (1997), observed that "in retrospect, what was striking was urgent and growing pressure for assessment, assessment, assessment: test everything and everyone for a score; don't trust teachers” (pp. 2223). According to Hamp-Lyons (2002, as cited in Taki and Heidari, 2011), the tendency for using portfolio assessment originated from writing assessment, "from indirect multiple choice tests to direct timed impromptu essay tests to portfolio-based writing assessment” (p.192). 
From 1980s onwards, portfolio assessment gained its popularity for two main reasons. "One driving force is growing dissatisfaction with timed impromptu essay tests. The other is the development of writing instruction. Instructional approaches in ESL/EFL writing have in some respects parallel developments in English L1 composition" (Taki and Heidari, 2011, p.192). Unlike the product-oriented model which is out of date, the process-oriented writing model is pervasive almost in all over the world (Hedgcock, 2005). According to process approach "it is unnatural for a learner to write a draft of composition and submit for a grade" (Cohen, 2001, p. 534). Thus, portfolio assessment may be the standard alternative instrument for assessing writing in ESL/EFL composition classrooms (Hedgcock, 2005; Weigle, 2002).

It seems that portfolio assessment has been a good substitute for traditional methods for assessing writing. According to many researchers (e.g. Delett, Barnhardt \& Kevorkian, 2001; Hamp-Lyons, 1995; Hamp-Lyons \& Condon, 2000; Song \& August, 2002), the use of portfolio is beneficial in both ESL/EFL contexts. The findings of many studies have revealed that the helpfulness of portfolio assessment has come from English L1 contexts, and the application of portfolio assessment to ESL/EFL contexts is less(Hamp-Lyons, 2001; Hirvela \& Pierson, 2000; Hirvela \& Sweetland, 2005; Liu, 2003; Weigle, 2002). Previous studies have indicated that European students are encouraged to make a decision on taking responsibility for their learning (Liu, 2003), while there are not adequate studies to investigate the use and value of portfolio assessment in EFL contexts in general, and in writing classrooms in particular.

Therefore, finding an influential way for assessing writing and its effect on the students' overall writing ability can be considered as a great importance in writing instruction. Since portfolio assessment has been proved to be a useful method of assessment, the purpose of the current research is, therefore, to investigate whether writing ability of the students are influenced by the portfolio assessment. Additionally, students' attitudes towards using portfolio are investigated through the following questions:

1. What is the impact of potfolio assessment on Iranian EFL students' writing?

2. What are the attitudes of the Iranian students towards the use of portfolio assessment?

\section{Review of related literature}

Portfolio assessment in writing is defined as "a collection of texts the writer has produced over a defined period of time" (Hamp-lyons, 1991, p. 262). The impact of portfolio assessment on the writing ability of Iranian EFL students has been investigated by Ghoorchaei, Tavakoli and Ansari (2010). The results of their study revealed that portfolio assessment empowered their writing ability. The formative role of portfolio assessment was emphasized by Lam and Lee (2009). The results of their study indicated that the students had positive attitudes towards the effect of formative portfolio assessment on their writing ability, and the instructors also highlighted the role of formative portfolio assessment.

Buyukduman and Sirin (2010) stated that "since education is inherently interdisciplinary, the only valuable way to measure learning is to make the assessment part of the learning process, ensuring it provides students with information on the quality of their learning" (p.56). The outcome of their research showed that portfolio caused the students take the responsibility, and it gave them an opportunity to learn at their own pace.

\section{Method}

\subsection{Participants}

The participants of the current study were 46 pre-intermediate Iranian male and female university students who were chosen from a larger group of 70 students. To be sure of homogeneity among the students, all the students were given an Oxford Placement Test. The students were 18-22 years old in English major in Islamic Azad University, Larestan branch. The researcher divided them randomly into two groups as control and experimental groups of 23 in each group. The students attended the writing class twice a week for 15 weeks in the 2013-2014 academic year.

\subsection{Instrumentation}

To be sure of the homogeneity of the students in terms of English proficiency, OPT was used as an instrument. During the term the students in the experimental group produced writing portfolios using Top Notch series by Saslow and Ascher (2008). In addition, a questionnaire was used to assess the students' perception toward using portfolio assessment in writing class and the effects of portfolio assessment on writing ability.

\section{Procedure}

In order to select 46 participants, the researcher administered an Oxford Placement Test. Then, he divided them into experimental and control groups of 23 students in each group. The whole participants attended the writing class twice a week for 15 weeks in the term. To identify the writing ability of the students, the students wrote two topics that had been selected from Oxford Placement Book. They wrote two essays one at the beginning of the term and one at the end of the term. In order to check their writing ability, the researcher used Pearson Education (2007) rubric with two different raters.

During the term, all the students in experimental group wrote five essays based on the topics in their course book. To evaluate the students' writings, word choice, ideas, sentence fluency, voice, and organization were checked by two 
experienced rates. The researcher tried to use those qualified raters who were familiar with the rubrics for scoring the students' writings.

In order to correct the students' writing papers, the researcher adapted the scoring rubric from Rog (2001). Before the raters check the assignments, the students had this opportunity to revise and then resubmit their papers. They tried their bests to apply the comments they received into their writing papers. In this case, the raters received the papers after revising the papers for three times. In contrast, the students in control group wrote five essays and they didn't receive any feedback from their teacher and also they didn't have any opportunity to revise their writing papers. To identify the students' attitudes in the experimental group towards using portfolio, they completed a questionnaire.

\section{Results}

To evaluate the effect of portfolio assessment on the writings of the Iranian students and to compare the performance of the students in experimental and control groups, a t-test was run. As it is shown in Table1, there is a significant difference $(p<0.05)$ between the mean scores of the students in experimental and control groups. In addition, the observed $t$-value $(t=2.29)$ reveals that it is high enough to reject the hypothesis that portfolio assessment is not effective to improve the students' writing. Thus, there is a statistically significant difference between the experimental and control groups. In other words, portfolio assessment is effective to improve the Iranian students' writing.

Table 1. Summary of the t-test for the experimental and control groups in posttest

\begin{tabular}{|c|c|c|c|c|c|c|c|c|}
\hline \multicolumn{2}{|c|}{$\begin{array}{l}\text { Levene's test } \\
\text { for equality of } \\
\text { variance }\end{array}$} & & & \multicolumn{5}{|c|}{ T-Test for Equality of Mean } \\
\hline \multirow[t]{2}{*}{$f$} & \multirow[t]{2}{*}{ Sig. } & \multirow[t]{2}{*}{$\mathrm{t}$} & \multirow[t]{2}{*}{$\mathrm{df}$} & \multirow[t]{2}{*}{ Sig. } & \multirow[t]{2}{*}{$\begin{array}{c}\text { Mean } \\
\text { Difference }\end{array}$} & \multirow[t]{2}{*}{$\begin{array}{l}\text { Std. Error } \\
\text { Difference }\end{array}$} & $\begin{array}{r}95^{\circ} \\
\text { Confid }\end{array}$ & \\
\hline & & & & & & & Lower & Upper \\
\hline 0.463 & 0.485 & -2.29 & 44 & 0.037 & -3.168 & 1.536 & -6.368 & 0.487 \\
\hline
\end{tabular}

To assess the students' reflection towards using portfolio assessment, a questionnaire was distributed among the students. The students in the experimental group were asked to respond the questions in the questionnaire. Collecting the questionnaires and analyzing them revealed that ideas and voice were considered as two important areas that need to be improved in writing. The results of the questionnaires also indicated that word choice and organization of the writing were other areas that the students had less problems and they were their strength in writing.

\section{Discussion and Conclusions}

The statistical analysis revealed that portfolio assessment had a positive effect on the students' writing ability. Tthis finding was in line with the results of studies by Bowie, Tayloor, Zimitat, and Young (2000). Although the students' abilities in writing were not significantly different at the beginning of the study, the implementing of portfolio assessment improved the scores of the students in the experimental group in comparison with those of the control group. Despite Herman, Gearhart, and Aschbacher (1996) believed that the effectiveness of portfolio assessment is under the question because there are not conclusive research in this area, the results of this study showed something else. They revealed that portfolio assessment is more effective in comparison to other forms of writing assessment. The current study also indicated that portfolio assessment concentrates on all aspects of writing like syntax, fluency, and content. In contrast to portfolio assessment, in other types of writing assessment the teachers just focus on some superficial features in the writing of the students. Regarding this issue, Moran (1982) states that while in traditional methods of assessment the teachers are influenced by some features like word usage, spelling, and length of paper, in portfolio assessment teachers focus on all aspects of writing.

\section{References}

Barrett, H. C. (2000). Electronic portfolios, school reform and standards. Barrett, Helen.

Biggs, J., \& Tang, C. (1997). Assessment by portfolio: Constructing learning and designing teaching. Research and Development in Higher Education, pp. 79-87.

Bowie, C., Taylor, P., Zimitat, C., \& Young, B. (2000). Electronic course portfolio in a new on-line graduate certificate in flexible learning. HERDSA News.

Buyukduman, L. \& Sirin, S. (2010). Learning portfolio (LP) to enhance constructivism and student autonomy. Procedia Social and Behavioral Science, 3, 55-61.

Cohen, A. D. (2001). Second language assessment. In M. Celce-Murcia (Eds.), Teaching English as second language (pp. 513-534). Boston: Heinle \& Heinle.

Cooper, T. (1997). Portfolio assessment: A guide for students. Perth: Praxis Education. 
Cooper, T. (1999). Portfolio assessment: A guide for lecturers, teachers and course designers. Perth: Praxis Education.

Cooper, T., \& Love, T. (2000). Portfolios in university-based design education. In C. Swann \& E. Young (Eds.), Re-inventing design education in the university (pp. 159-166). Perth: School of Design, Curtin University.

Delett, J. S., Barnhardt, S., \& Kevorkian, J. A. (2001). A framework for portfolio assessment in the foreign language classroom. Foreign Language Annals, 34 (6), 559-568.

Dysthe, O. (2008). The challenges of assessment in a new learning culture. In A. Havnes \& L. McDonald (Eds.), Balancing dilemmas in assessment and learning in contemporary education (pp. 15-32), New York: Routledge.

Elbow, P., \& Belanoff, P. (1997). Reflections on the explosion: Portfolio in the 90s and beyond. In K. B. Yancey (Ed.), Situating portfolios (pp. 21-33). Logan: Utah States University Press.

Ghoorchaei, B. Tavakoli, M. \& Nejad Ansari, D. (2010). The impact of portfolio assessment on Iranian EFL students"e essay writing: A process-oriented approach. GEMA Online Journal of Language Studies, 10 (3), 35-51.

Hamp-Lyons, L. (1995). Portfolios with ESL writers: What the research shows. Paper presented at the annual convention of Teachers of English as a Second Language, Long Beach, CA.

Hamp-Lyons, L. (2001). Fourth generation writing assessment. In T. Silva \& P. K. Matsuda (Eds.), On second language writing (pp. 117-128). Mahwah, NJ: Lawrence Erlbaum.

Hamp-Lyons, L. (2002). The scope of writing assessment. Assessing Writing, 8, 5-16.

Hamp-Lyons, L. \& Condon, W. (2000). Assessing the portfolio: Principles for practice, theory, and research. New Jersey: Hampton Press.

Hedgcock, J. S. (2005). Taking stock of research and pedagogy in L2 writing. In E. Hinkel (Eds.), Handbook of

research in second language teaching and learning. Mahwah, NJ: Lawrence Erlbaum. 579-614.

Hedge, T. (2000). Teaching and learning in the language classroom. Oxford: Oxford University Press.

Herman, J. L., Geahart, M., \& Aschbacher, P. R. (1996). Portfolios for classroom assessment: Design and implementation issues. In R. Calfee \& P. Perfumo (Eds.), Writing portfolios in the classroom: Policy and practice, promise and peril (pp. 27-59). Hillsdale, NJ: Lawrence Erlbaum Associates.

Hirvela, A. \& Pierson, H. (2000). Portfolios: Vehicles for authentic self-assessment. In G. Ekbatani \& H. Pierson (Eds.), Learner-directed assessment in ESL (pp. 105-126). Mahwah, NJ: Lawrence Erlbaum Associates, Publishers

Hirvela, A., \& Sweetland, L. (2005). Two case studies of L2 writers' experiences across learning directed portfolio contexts. Assessing Writing, 10, 192-213.

Lam, R. \& Lee, I. (2010). Balancing the dual functions of portfolio assessment. ELT Journal Volume 64 (1), 54-64

Liu, Y. (2003). A case study of selected ESL students' experiences with writing portfolios in college composition courses. Unpublished doctoral dissertation. Ohio State University.

Moran, M. R. (1982). Analytical evaluation of formal written language skills as a diagnostic procedure.

Diagnostique, 8, 17-31.

Song, B. \& August, B.( 2002). Using portfolios to assess the writing of ESL students: A powerful alternative? Journal of Second Language Writing, 11(1), 49-72.

Taki, S. \& Heidari, M. (2011). The effect of using portfolio-based writing assessment on language learning: The case of young Iranian EFL learners

Weigle, S. C. (2002). Assessing writing. Cambridge: Cambridge University Press. 